\title{
Entrepreneurship Advancement and Malaysia Immigrant Policy: A Conceptual Analysis
}

\author{
Ayotunde Adetola Adelaja (Corresponding author) \\ School of Business Management, Universiti Utara Malaysia \\ E-mail: ayoadelaja@live.com
}

Received: February 10, 20120 Accepted: March 17, $20120 \quad$ Published: April 11. 20120

doi:10.5296/rbm.v7i2.16830 URL: http://dx.doi.org/10.5296/rbm.v7i2.16830

\begin{abstract}
The migration process in the $21^{\text {st }}$ century has become a global phenomenon to the extent that governments are in huge competition to make their place migration destination specifically for international students due to several skills, knowledge and entrepreneurial ideas they have. Owing to these reasons, this paper conceptually analyze the prospect and challenges of integrating from entrepreneurial lens international students into the Malaysian entrepreneurship atmosphere. Considering this, it is suggested in this study that Malaysia entrepreneurship policy should be inclusive to embrace foreign participation. Also, the immigrant policy which has increased the flow of international students needs to be complemented with freedom to engage in a legal business activities. It is therefore conceptually opined that the amendment of the immigrant policy which should be regulated will increase the attitudinal change towards Malaysia generally and it would place the entrepreneurship policy more viable.
\end{abstract}

Keywords: Migrant Entrepreneurship, Globalization, Government Policy, International students, Entrepreneurship Development.

\section{Introduction}

Migration in the 21 st century has become a global phenomenon. However, the concept of migration itself seems to be changing with time. In the 19th century, the notion of migration was associated with the movement of populations from zones of wants and misery to zones of enterprise and prosperity where people can engage in commerce and prosper (Papastergiadis, 2018; Perlik \& Membretti, 2018; Todes \& Turok, 2018; Toro-Morn \& Alicea, 2004). Nevertheless, the purpose of migration differs. However, this study is imperative as it takes a look at international students in Malaysia and the immigration policy towards their entrepreneurship engagement. Given this, migration is described to include the movement of students from their home country to countries that tend to provide post-secondary education that meet their needs. 


\section{Macrothink}

Research in Business and Management

ISSN 2330-8362

2020, Vol.7, No.2

It is acknowledged that human migration is a complex process influenced by factors such as uneven distribution of resources, and what can be summarized as basic factors of production as well as advanced factors such as biological, medical, social as well as educational factors (Bhugra \& Becker, 2005; Cacioppo, Berntson, Sheridan \& McClintock, 2000; Lutz \& Belanger, 2017; Zhou, Jindal-Snape, Topping, \& Todman, 2008). With an emphasis on education as a significant source of migration among youths in recent times, several governments support and sponsor these factors via several means such as educational scholarship and internationalization agenda. For example, the United States of America, the government of Canada, United Kingdom, France (Stein, Metcalfe, Trilokekar \& Beck, 2019; Wang \& Long, 2019; Wu \& Zha, 2018), as well as the Malaysian government (Armstrong \& Laksana, 2016; Shahijan, Rezaei \& Preece, 2016).

In lieu of this, it is pertinent to explore the immigration system of Malaysia via a vis entrepreneurship policy for international students. The paper is divided into six sections. Asides the introductory aspect that gives background information on the subject matter, the second segment looks at the agenda of Malaysia Higher education. The third section considers the entrepreneurship policy in Malaysia while the fourth segment centers on Malaysia's labor policy for immigrants. The fifth section talks on the prospects and challenges while the concluding remark surfaces in the sixth chapter.

\section{Malaysian Higher Education Internationalization Agenda}

Bids to attract foreign or international students to choose Malaysia as a study place influence the Malaysian government to formulate and implement several 'enticing policies' not limited to financial support, quality assurance of cross-border educational initiatives, recognition of oversea certificates, and allocation of $5 \%$ of seats for international students to study medicine and pharmaceutical courses. As such, as of the year 2015, the Malaysian government recorded about 90,000 international students representing more than $70 \%$ of Malaysia inbound total in that same year (Luo, 2017). Yet, Malaysia continues to compete for larger market share in international students' enrollment and by the end of the year 2025, they plan to enroll about 250,000 of international students to their local post-secondary institutions under the Malaysia Higher Education Blueprint 2015-2025 (ICEF Monitor, 2016; Jusoh, 2017). Achieving this, it was estimated that the expected revenue will jump to around 15.6 billion Malaysian Ringgit (Stacey, 2019) reporting the speech of Mohd Ghazali Abas who was the education ministry secretary-general.

Meanwhile, from the entrepreneurial development lens, less is done in integrating the invited international students who may wish to extend their stay in the Malaysian society and contribute their post-secondary educational economic quota into the Malaysian economy. As evidence from several scholarly articles, immigrant policy documents, and news portals, the available policy thrust is centered on attracting talents (ICEF Monitor, 2016; Jusoh, 2017; Luo, 2017). While other aspect of the available policy focus on 'low skilled immigrant labor' targeting workers from neighboring Asian states such as Indonesia, Vietnam, Cambodia, India, Bangladesh, and Thailand to name few (Devadason \& Meng, 2014; Kaur, 2008; Nel \& Abdullah, 2019) due to labor shortages in some area of the Malaysian economy. 


\section{Macrothink $\Lambda$ Institute}

Unlike other established higher education hub, for example, Germany, Australia, Singapore, United Kingdom, Canada, France, Hong Kong and the Switzerland where there are fewer restrictions on students' immigration in economic and business-related categories that might entice and attracts international students with high entrepreneurial mindset as well as retaining these students of high pedigree after postgraduate graduation (State of Immigration, 2015). There are indications that Malaysia has a work and study policy which allow students to work for hours not more than 20 hours a week only in holidays that stretch over 7 days, nevertheless, the implementation of this policy 'may never' exist due to high bureaucracy and the government policies to keep jobs for Malaysian nationals before any other countries (Devadason \& Meng, 2014; Horrocks, 2018; Singha, 2019).

The government of Malaysia had significantly invested and continue to make significant investment in developing entrepreneurship via implementation several entrepreneurial policies to cater for the needs of entrepreneurship at several stages ranging from new firm creation to industrialization and commercialization, training Malaysian citizens on ways to become entrepreneurs, financing several entrepreneurial projects, conferences and seminars (Hubka \& Zaidi, 2005; New Strait Times, 2019; Nor, 2015). One of the differences in the approaches to encourage students' migration is that most of the countries from the western world are tapping into the resource diversity among the invited students to create and sustain their economy either directly through friendly policies that grant the students stay after their required education period, or relaxed policies that allow the students to be engaged in some sort of employment during their education period. These have its own pros and cons. However, studies from the western world have it that the advantages of immigrant entrepreneurial actions superseded the adversaries in terms of job creation and new firm startups (Bhachu, 2017; Gibson et al., 2018; Wang \& Warn, 2018). This leads to the subject topic of immigrant entrepreneurship.

The contribution of transnational or trans-border entrepreneurship in recent times is gaining interest from scholars (Brzozowski, Cucculelli \& Surdej, 2017; Kerr \& Kerr, 2016; Picot \& Rollin, 2019). Immigrant entrepreneurship has been argued to serve as a route to social ties advancement and mobilization, and channel for economic advancement, significant source of diversified new firm creation reduces labor shortages, and introduction of new skills and knowledge (Gibbs, Singh, Butler \& Scott, 2018; Kerr \& Kerr, 2016; Light, Bhachu, \& Karageorgis, 2017; Razin, 2017). Statistics revealed that on average, $25 \%$ of new businesses in the entire United States (US) are the works of immigrant entrepreneurs while some states in the US have around $40 \%$ new firms created by immigrant entrepreneurs. Examples of immigrant entrepreneurship in the US is the iconic Silicon Valley and other similar tech hubs (Kerr \& Kerr, 2020). Similarly, statistics by Picot and Rollin (2019) estimates that in Canada, immigrant-owned firms occupy a $25 \%$ net of new jobs created.

Regardless of the positive economic impacts of immigrant entrepreneurship as revealed by scholars mentioned above, there are scientific evidences that immigrant entrepreneurship is a source of major competitors to local entrepreneurial business (Picot \& Rollin, 2019). On the contrary, transnational entrepreneurship contributes more to local entrepreneurship mobilization (Picot \& Rollin, 2019; Zhou \& Liu, 2015). As evidence, scholars and economic 
policymakers had invested significant effort to explore and investigates the significance of immigrant entrepreneurship (Griffin-EL \& Olabisi, 2018; Gurău, Dana \& Katz-Volovelsky, 2020; Guercini, Dei Ottati, Baldassar, L., \& Johanson, 2017; Osaghae \& Cooney, 2019; Njoku \& Cooney, 2018).

Besides, as identified in the study of Gibson et al. (2018), the editorial comments reveal that although there are numerous studies on immigrant entrepreneurship, this concept is still at its infancy stage, exploring immigrant entrepreneurship from a new perspective and incorporating environmental characteristics are among the few issues that needed attention. Earlier studies have it that, environmental opportunity identification, migration histories, and structural artifact in home and host countries, resource availability, host country characteristics as per policies, ethnicity and location interaction (Bhachu, 2017; Wang \& Warn, 2018) are some of the few factors that influence, instigate and enhance immigrants entrepreneurship specifically in the western world.

\section{Entrepreneurship Policies in Malaysia}

Malaysia over the years had implemented several economic policies targeted at eradicating the economic gap among the races in the country. Examples of these policies include the Rural Industrial Development Authority (RIDA) created in the year 1951 targeted in encouraging 'Bumiputera' entrepreneurship in all sectors. This policy was improved and renamed in the year 1966 as Council of trust for Indigenous People or MARA (Beaglehole, 1969; Hubka \& Zaidi, 2005).

Subsequently, in the year 1970, the government of Malaysia introduces the New Economic Policy (NEP) to balance racial economies. Under this policy, equal opportunities were administered to business creation as well as the 'bumiputras' were encouraged to venture into businesses. Every five years this policy was revised and improved leading to the implementation of developmental policies that encourage bumiputras' commercialization and industrialization. To complement this, Entrepreneurship and Cooperative Development were inaugurated in the year 2004 however, it was dissolved five years later, its functions were spread over different ministries (Nor, 2015).

Besides, several entrepreneurship development policies such as 1Malaysia Entrepreneur, Tekun Nasional, Amanah Ikhtair, Graduate Entrepreneurship Fund, was introduced to train, provide support and resources to Malaysian entrepreneurs at different economic and social levels (Nor, 2015). While in recent times, the country's focus is the National Entrepreneurship 2030 aiming to inculcate entrepreneurship culture and aspire that entrepreneurship can contribute around $50 \%$ of the national gross domestic product (GDP) by the year 2030 (New Strait Times, 2019). Considering these, there are indications that the government of Malaysia made and continuously making adequate provisions to enhance local entrepreneurship development in Malaysia with the aspiration of diversifying and sustaining the economy.

\section{Immigrant Labor Policies and Entrepreneurial Activities in Malaysia}

Some evidence found reveals Malaysia to have policies that encourage investment and integration. However, for already established investor under the policy Malaysia my second 
home (MM2H), the conditions for application is nearly impossible for an immigrant entrepreneur within the scope of this study, that is, international students invited to study in Malaysia to fulfill such requirements. Some of the requirements according to the MM2H website:

"Applicants under the age of 50-year-old must have a fixed account with a minimum balance of 300,000 Malaysian Ringgit, a minimum monthly income, minimum liquid assets and several other conditions not feasible for young migrants' entrepreneurs to fulfill at the startup stage."

Although no tangible documents express the role of policies to establish immigrants' entrepreneurship activities in Malaysia, yet, there are evidences that entrepreneurial activities spawn among the immigrants' societies wherever they clustered. Examples of informal entrepreneurial activities commonly found among immigrant entrepreneurs are not limited to entertainment entrepreneurship, restaurant chain supplying the migrant population their home food and foodstuffs, boutiques where home apparels are sold and hair salon (Gordon, 2017). Most of these immigrant students engage in various entrepreneurial activities due to push factors such as avenue to raise money to cater to their self (Sakılığlu \& Lees, 2019; Shinnar $\&$ Young, 2008). Thus, legalizing these entrepreneurial activities by registering their company under trade laws in a country such as Malaysia remains a complex issue. Therefore, they are being termed as illegal business operators causing the government to go after unregistered businesses and shutting them down. With this, immigrant students have perceived Malaysian policy on entrepreneurship not friendly for international students (Joseph, 2017).

\section{Prospect and Challenges}

No doubt, Malaysia remains an emerging economy not only in South East Asia but across the global market. The nationalization of economic policy has increased the empowerment of the nationals of the country. This is good for strengthening the indigenous viability in the area of entrepreneurship development. The enhancement of small scale business among Malaysians is glaring and the level of productivity has improved. Such a dimension could be categorized as a breakthrough approach for the average nationals.

However, the current global trend has challenged the entrepreneurship focus to be all-inclusive. The inclusiveness requires diversification and a free market economy that allows foreigners active participation in the entrepreneurs' sector. The advanced economies in the world can reach the hallmark through an open market system that does not only encourage the nationals to be viable economically but also creates better chances for immigrants to thrive in small, medium and large scale businesses. The need to improve immigrant policy for business advancement would make entrepreneurship more dynamic particularly in the area of small scale business. More importantly, the skills acquired by immigrants can be effectively utilized to suit the Malaysian environment. As obtainable, the United Kingdom, the international students are given the privilege to work and partake in some small businesses which ordinarily the indigenous might not show interest in. The reward for such labor is minimal but mostly 
complements the financial status of the immigrant students. This is a good booster for the business environment and also enhance the capacity of demand and supply in the society.

Not only that, the Malaysian minimum wage is another angle that necessitates the amendment of immigrant policy. The immigrants can engage in a job with wages below the national minimum wage. Though the government is expected to have a regulatory body to avoid its abuse, the international students primarily have the intention to acquire certificates. The payment will be appreciated as it serves as a booster for entrepreneurs to translate theory into practice. The minimum wage of $1000 \mathrm{RM}$ can be reviewed downward for the immigrants particularly students. The essence is to create a friendly entrepreneurial environment for international to showcase their respective potentials while in the host country.

In the final analysis, the labor, business, and market structure of Malaysia has the prospect of being expanded if the immigration policy becomes friendlier for international students. This will not only boom business activities in the country, but it would also allow collaboration and partnership of small, medium and large enterprises.

\section{Conclusions}

The issue of entrepreneurship is beyond conceptualization. It requires practical direction to distinct it from other theoretical based fields. This makes it all-encompassing that does not believe in stratification along with nationalities. The focus of business thrives as projects by entrepreneurship allow free entry and exit of competent stakeholders. This informs the argument of this paper that Malaysia entrepreneurship policy should be inclusive to embrace foreign participation. The immigrant policy which has increased the flow of international students needs to be complement with the freedom to engage in legal business activities. Encouraging small and medium enterprises among the immigrants would serve as a better economic booster for the country. This can be done by protecting the national interest as immigrants can be healthy competitors for the indigenous business acumen. The amendment of the immigrant policy which should be regulated will increase the attitudinal change towards Malaysia generally and it would place the entrepreneurship policy more viable. This is also a plus towards the advancement of the Malaysian economy and the prospect of joining the league of developed nations.

\section{Reference}

Armstrong, N., \& Laksana, S. (2016). Internationalization of higher education: case studies of Thailand and Malaysia. Scholar: Human Sciences, 8(1), 102.

Beaglehole, J. H. (1969). Malay participation in commerce and industry: The role of RIDA and MARA. Journal of Commonwealth \& Comparative Politics, 7(3), 216-245.

Bhachu, P. (2017). Immigration and entrepreneurship: culture, capital, and ethnic networks. Routledge.

Bhugra, D., \& Becker, M. A. (2005). Migration, cultural bereavement and cultural identity. World psychiatry, 4(1), 18. 
Brzozowski, J., Cucculelli, M., \& Surdej, A. (2017). The determinants of transnational entrepreneurship and transnational ties' dynamics among immigrant entrepreneurs in ICT sector in Italy. International Migration, 55(3), 105-125.

Cacioppo, J. T., Berntson, G. G., Sheridan, J. F., \& McClintock, M. K. (2000). Multilevel integrative analyses of human behavior: Social neuroscience and the complementing nature of social and biological approaches. Psychological bulletin, 126(6), 829.

Devadason, E. S., \& Meng, C. W. (2014). Policies and laws regulating migrant workers in Malaysia: A critical appraisal. Journal of Contemporary Asia, 44(1), 19-35.

Gibbs, S., Singh, R. P., Butler, J. S., \& Scott, C. (2018). The role of networking, entrepreneurial environments, and support systems in the creation, survival and success of ventures founded by minority, women, and immigrant entrepreneurs. New England Journal of Entrepreneurship.

Gordon, R. J. (2017). The rise and fall of American growth: The US standard of living since the civil war (Vol. 70). Princeton University Press.

Horrocks, L. (November 13, 2018). Post-study visa options in Malaysia. Retrieved from: https://www.hotcoursesabroad.com/study-in-malaysia/visa-guides/work-after-graduati on-in-malaysia/

Hubka, A., \& Zaidi, R. (2005). Impact of government regulation on microfinance.

ICEF Monitor (2016). Malaysia competing for a greater share of international students. Retrieved from:

https://monitor.icef.com/2016/08/malaysia-competing-greater-share-international-stud ents/

Joseph, I. (2017). Factors influencing international student entrepreneurial intention in Malaysia. American Journal of Industrial and Business Management, 7(04), 424.

Jusoh, S. I. (May 7, 2017). Under our Malaysia Education Blueprint 2015-2025 (Higher Education), we are aiming to attract 250,000 international students by 2025 . Retrieved from:

https://www.nst.com.my/opinion/columnists/2017/05/237032/turning-world-towardsmalaysian-education

Kerr, S. P., \& Kerr, W. (2020). Immigrant entrepreneurship in America: Evidence from the survey of business owners 2007 \& 2012. Research Policy, 49(3), 103918.

Kerr, S. P., \& Kerr, W. R. (2016). Immigrant entrepreneurship (No. w22385). National Bureau of Economic Research.

Light, I., Bhachu, P., \& Karageorgis, S. (2017). Migration networks and immigrant entrepreneurship. In Immigration and entrepreneurship (pp. 25-50). Routledge.

Luo, N. (2017). Japan, Malaysia, Taiwan, and South Korea Remap Regional Student Flows. World Education News Review. WENR. Retrieved from: 
https://wenr.wes.org/2017/08/global-mobility-japan-malaysia-taiwan-and-south-korea -seek-to-shift-student-mobility-by-2025

Lutz, W., \& Belanger, A. (2017). Demographic change and the drivers of future migration into Europe. Approach, methodology and work plan of the JRC/IIASA Centre of Expertise on Population and Migration.

New Strait Times (July 11, 2019). New policy to drive entrepreneurs. Retrieved from: https://www.nst.com.my/news/nation/2019/07/503403/new-policy-drive-entrepreneur s. Accessed on: February 6, 2020.

Njoku, K. C., \& Cooney, T. M. (2018). Understanding How Immigrant Entrepreneurs View Business Opportunity Formation Through Ethnicity. Creating Entrepreneurial Space: Talking Through Multi-Voices, Reflections on Emerging Debates, 49.

Nor, N. A. A. M. (2015). Entrepreneurship development policy in Malaysia. Economic and Social Science Research Centre, MARDI, Persiaran MARDI-UPM, http://ap. fftc. agnet.org/ap_db.php.

Papastergiadis, N. (2018). The turbulence of migration: Globalization, deterritorialization and hybridity. John Wiley \& Sons.

Perlik, M., \& Membretti, A. (2018). Migration by necessity and by force to mountain areas: An opportunity for social innovation. Mountain Research and Development, 38(3), 250-264.

Picot, G., \& Rollin, A. M. (2019). Immigrant Entrepreneurs as Job Creators: The Case of Canadian Private Incorporated Companies (No. 2019011e). Statistics Canada, Analytical Studies Branch.

Razin, E. (2017). Immigrant Entrepreneurs in Israel, Canada, and California. In Immigration and entrepreneurship (pp. 97-124). Routledge.

Sakızlığlu, B., \& Lees, L. (2019). Commercial Gentrification, Ethnicity, and Social Mixedness: The Case of Javastraat, Indische Buurt, Amsterdam. City \& Community.

Shahijan, M. K., Rezaei, S., \& Preece, C. N. (2016). Developing a framework of internationalisation for higher education institutions in Malaysia: a SWOT analysis. International Journal of Management in Education, 10(2), 145-173.

Shinnar, R. S., \& Young, C. A. (2008). Hispanic immigrant entrepreneurs in the Las Vegas metropolitan area: motivations for entry into and outcomes of self-employment. Journal of Small Business Management, 46(2), 242-262.

Singha, R. (Aug 14, 2019). Study in Malaysia: Are students allowed to work part-time? Retrieved from: https://studyabroad.shiksha.com/study-in-malaysia-are-students-allowed-to-work-part -time-articlepage-654 
Stacey, V. (Sep 27, 2019). Malaysia to recalibrate its strategy as 200k int'l student target by 2020 looks unlikely. The Pie News. Retrieved from:

https://thepienews.com/news/malaysia-to-recalibrate-strategy-as-200000-target-looksout-of-reach/

State of Immigration (March, 2015). How the United States Stacks Up in the Global Talent Competition. Business Roundtable

Stein, S., Metcalfe, A. S., Trilokekar, R. D., \& Beck, K. (2019, January). Critical Conversations about the Internationalization of Canadian Higher Education. In 2019 Conference of the Canadian Society for the Study of Education.

Todes, A., \& Turok, I. (2018). Spatial inequalities and policies in South Africa: Place-based or people-centred?. Progress in Planning, 123, 1-31.

Toro-Morn, M. I., \& Alicea, M. (Eds.). (2004). Migration and immigration: a global view. Greenwood Publishing Group.

Wang, J., \& Long, F. (2019). Analysis of the Relationship between Internationalization and the Quality of Ed. D. in USA. Education Research Frontier, 9(4).

Wang, Y., \& Warn, J. (2018). Chinese immigrant entrepreneurship: Embeddedness and the interaction of resources with the wider social and economic context. International Small Business Journal, 36(2), 131-148.

Wu, H., \& Zha, Q. (2018). A new typology for analyzing the direction of movement in higher education internationalization. Journal of Studies in International Education, 22(3), 259-277.

Zhou, M., \& Liu, H. (2015). Transnational entrepreneurship and immigrant integration: new Chinese immigrants in Singapore and the United States. Immigration and work (Research in the Sociology of Work, vol 27). Emerald Group, 27, 169-201.

Zhou, Y., Jindal-Snape, D., Topping, K., \& Todman, J. (2008). Theoretical models of culture shock and adaptation in international students in higher education. Studies in higher education, 33(1), 63-75.

\section{Copyright Disclaimer}

Copyright reserved by the author(s).

This article is an open-access article distributed under the terms and conditions of the Creative Commons Attribution license (http://creativecommons.org/licenses/by/3.0/). 